\title{
Ehlers-Danlos Syndrome associated with cardiomyopathy hypertrophic obstructive*
}

\author{
Raimundo José Almeida de Oliveira Pinto ${ }^{1}$ \\ Mablo de Castro Azevedo ${ }^{1}$
}

\author{
Adaílton Araújo dos Santos ${ }^{1}$ \\ Saulo Sacramento Meira ${ }^{1}$
}

DOI: http:/ /dx.doi.org/10.1590/abd1806-4841.20153824

\begin{abstract}
A bstract: Ehlers-Danlos syndrome is a rare clinical condition caused by a genetic change that results in the formation of structurally or functionally altered collagen. The clinical manifestations are varied, being the most obvious skin hypermotility and increased joint flexibility, although other systems - such as cardiovascular, respiratory and neurological - may also be affected. This paper presents the report of a patient who sought medical attention with complaints of atypical chest pain. Clinical evaluation enabled hypothetical diagnosis of hypertrophic obstructive cardiomyopathy and Ehlers-Danlos syndrome. Initial electrocardiogram, echocardiogram and 24 hours holter allowed the confirmation of the first hypothesis. A skin biopsy performed later associated clinical data and confirmed the second hypothesis.
\end{abstract}

Keywords: Cardiomyopathy, Hypertrophic; Ehlers-Danlos Syndrome; Tenascin

\section{INTRODUCTION}

Ehlers-Danlos Syndrome (EDS) is characterized by a genetic defect that leads to production of abnormal collagen, resulting in modification of synthesis and structure of connective tissue. ${ }^{1}$ It has a varied pattern of transmission and heterogeneous phenotype with autosomal dominant inheritance in most cases, although some patients present autosomal recessive inheritance pattern, which is closely associated with deficiency of tenascin X (TNX). ${ }^{2,3}$

Although EDS is associated with a diversity of cardiovascular problems, such as mitral valve prolapse and aortic rupture, with risk of sudden death, literature doesn't show its association with Obstructive Hypertrophic Cardiomyopathy (OHC), which makes this an unprecedented report.

This paper describes the story of a patient who concurrently presented EDS and OHC, as well as a theory that attempts to explain the benign prognosis of the patient cardiomyopathy.

The project was submitted and approved by the Ethics Committee of the Universidade Estadual do Sudoeste da Bahia - UESB, Jequié-Bahia, under the number CAAE 09712612.00000.0055.

\section{CASE REPORT}

Female patient, 68 years old, single, sought treatment with a history of atypical chest pain, not associated with physical effort or emotional stress. She also reported palpitations and dyspnea caused by efforts greater than usual, and referred to sporadic dizziness but no syncopes. In the clinical evaluation, the patient complained of algia on lower limbs associated with weakness when she had to be standing for long periods. In past history, the patient declared started walking when she was 5 years old, and that she had spontaneous dislocations in the knee joints and temporomandibular joint during adolescence. Furthermore, she reported to have a family history of schizophrenia.

In the physical examination, patient showed: $\mathrm{PR}=51 \mathrm{bpm} ; \mathrm{PA}=100 \times 60 \mathrm{mmHg}$; soft skin, velvety and hyperextensible, with colored mucosa; cephalic segment: no signs of abnormalities. Neck without jugular stasis; respiratory auscultation: no signs of abnormalities; cardiovascular system: ictus in the fifth left intercostal space $1.5 \mathrm{~cm}$ out of the mid clavicular line, impulsive $(+)$ covering a fingertip;

Conflict of Interest: None.

1 Universidade Estadual do Sudoeste da Bahia (UESB) - Jequié (BA), Brazil.

(C)2015 by Anais Brasileiros de Dermatologia 
impalpable murmur, palpable systolic murmur at the left sternal border; B1 hypophonetic sound $(+)$, B2 unfolding the inhaling with B2A > B2P, B4 in the mitral area; systolic ejection murmur grade IV/VI audible throughout the left sternal border; abdomen: liver and spleen impalpable; short, colored extremities and hyperextensible joints especially the metacarpophalangeal, scapulohumeral and ankles (Figure 1).

In the imaging examination, electrocardiogram showed first degree atrioventricular block and left chamber overload; chest X-ray showed cardiomegaly caused by left ventricle. Echocardiogram revealed mild enlargement of the left atrium, asymmetric septal hypertrophy with mild left ventricular outflow tract obstruction and moderate left venticular diastolic dysfunction (Figure 2). The 24-hour Holter monitoring detected nonsustained supraventricular tachycardia (Figure 3). Patient also underwent skin biopsy, which confirmed the reduction of collagen fibers of the papillary dermis, suggesting EDS (Figure 4).

\section{DISAUSSION}

TNX is an extracellular matrix glycoprotein that belongs to the tenascin family. It is associated with collagen fibers and acts as elastic bands, connecting
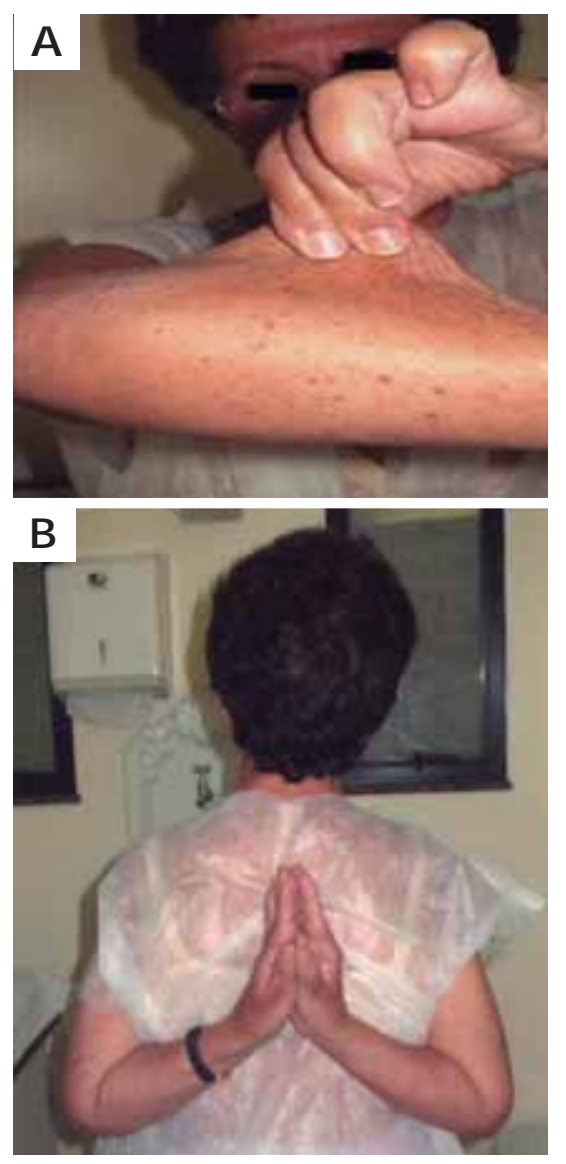

FiguRe 1:

Photographs showing classic features of Ehlers-Danlos Syndrome.

A) Cutaneous hyperextensibility. B) Joint hypermobility
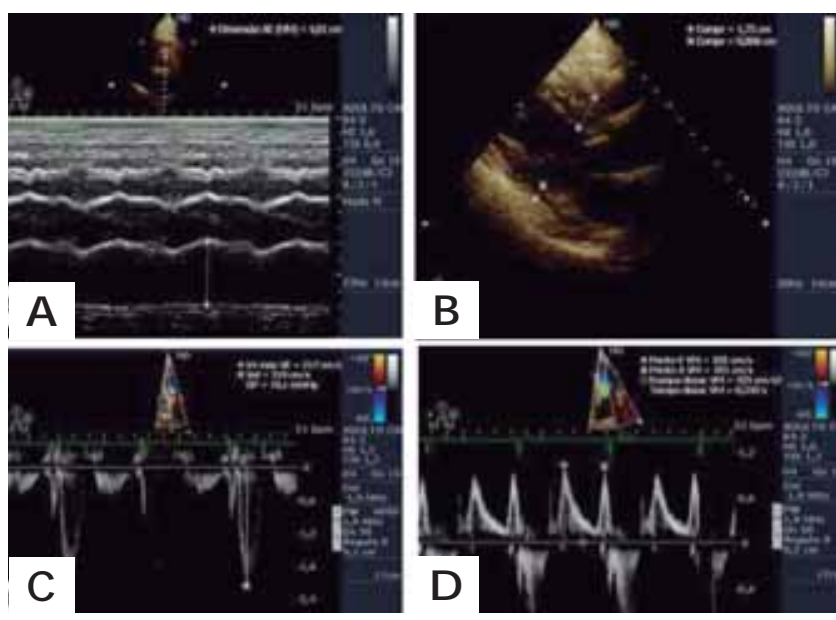

FiguRE 2: Doppler echocardiography. A ) Slight enlarged left atrium. B) Septal hypertrophy. C) Left ventricular outflow tract obstruction. D) Left ventricular diastolic dysfunction. Both findings show that this is an obstructive hypertrophic cardiomyopathy
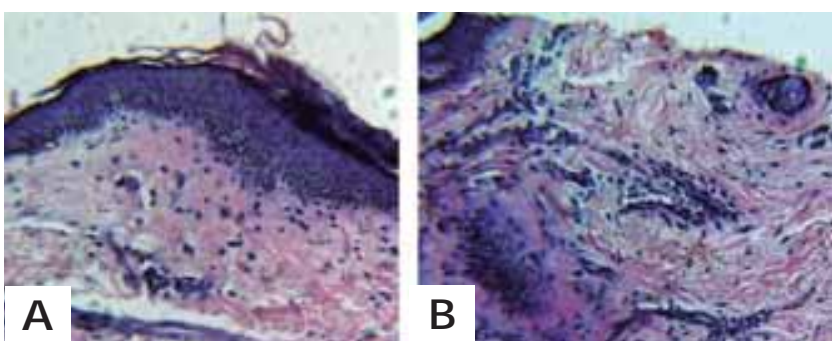

FIgURE 3: Samples stained with HE and Verhoeff method. The image shows a decrease in collagen density in the papillary and reticular dermis

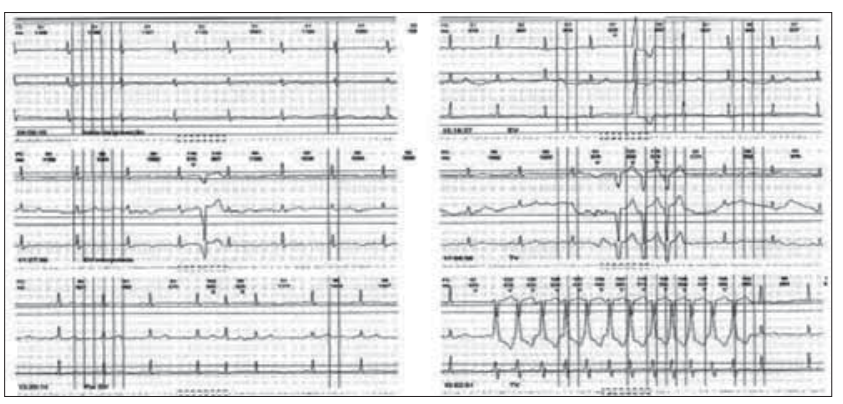

FIgURE 4: 24-hour Holter showing the presence of nonsustained ventricular tachycardia

adjacent collagen fibers and limiting the deformation capacity of the matrix. ${ }^{4}$ Presenting cell binding sites through integrin proteins, it is able to transmit stimuli of several types of force to cells. These stimuli act on the matrix inducing fibroblasts to produce the amount and type of matrix needed for supporting them. ${ }^{5}$ Any impairment or reduction of this protein can affect the composition of the extracellular matrix, resulting in joint hypermobility and connective tissue sagging. ${ }^{6}$ 
A particularly important feature is that patients with EDS associated with TNX deficit tend to not exhibit atrophic scars. From this information, we observed through clinical evaluation and heredogram conduction the presence of the first 2 characteristics, suggesting that EDS reported in this case is in fact associated with TNX deficit.

In the myocardium, collagen plays important functions such as connection of adjacent bundles of myocytes, maintaining the alignment of contractile elements and forming a web with greater rigidity than myocytes, preventing them from being excessively stretched and torn. ${ }^{7,8}$

$\mathrm{OHC}$ is a clinical manifestation of autosomal dominant transmission caused by genetic mutation that encodes sarcomere proteins. It is characterized by myocardial growth, causing hypertrophy and odd structural disorganization of cardiomyocytes in a diffuse way as well as fibrosis of varying degrees, being listed in the genesis of ventricular arrhythmias, which in turn are related to the risk of sudden death. ${ }^{9,10}$

We have, therefore, two diseases in a single patient, both genetic, and the concomitance suggests

\section{REFERENCES}

1. Lages PSM, Lima BMM, Ximenes AC. Síndrome de Ehlers-Danlos: atualização. Estudos. 2006;33:853-61.

2. Nomura ML, Surita F, Parpinelli MA. Síndrome de Ehlers-Danlos e gravidez: relato de caso. Rev Bras Ginecol Obstet. 2003;25:745-8.

3. Makareeva E, Cabral WA, Marini JC, Leikin S. Molecular mechanism of alpha 1 (I)-osteogenesis imperfecta/Ehlers-Danlos syndrome: unfolding of an $\mathrm{N}$-anchor domain at the N-terminal end of the type I collagen triple helix. J Biol Chem. 2006;281:6463-70.

4. Schalkwijk J, Zweers MC, Steijlen PM, Dean WB, Taylor G, van Vlijmen IM, et al. A recessive form of the Ehlers-Danlos syndrome caused by tenascin- $X$ deficiency. $N$ Engl J Med. 2001;345:1167-75.

5. Moriscot AS, Carneiro J, Abrahamsohn PA. Histologia para Fisioterapia e outras áreas da Reabilitação. Rio de Janeiro: Guanabara-Koogan; 2004.

6. Zweers MC, Hakim AJ, Grahame R, Schalkwijk J. Joint hypermobility syndromes: The pathophysiologic role of tenascin $X$ gene defects. Arthritis Rheum. 2004;50:2742-9

7. Menoni-Blanco BJ, Marrero NP, Lopes JA. Cardiopatía valvular en fase dilatada en paciente con Síndrome de Ehlers-Danlos. Cimel. 2010;15:31-3.

8. Milanez M. Efeitos do uso de captopril sobre o conteúdo de colágeno cardíaco e em parâmetros ponderais e hemodinâmicos após infarto do miocárdio em ratos [dissertação]. Vitória (ES): Universidade Federal do Espírito Santo; 1995. 128 p.

9. Almeida D, Viégas R, Silveira J, Godoy H. Diagnóstico Diferencial das Miocardiopatias In: Stefanini E, Kasinski N, Carvalho AF, editores. Guia de Cardiologia. 2. ed. ed. São Paulo: Manole; 2004. p. 311-20.

10. Mattos BPE, Torres MAR, Freitas VCd, Scolari FL, Loreto MSd. Arritmias ventriculares e hipertrofia ventricular esquerda na cardiomiopatia hipertrófica. Arq Bras Cardiol. 2013;100:452-9. a better prognosis of the $\mathrm{OHC}$, according to our hypothesis. The synthesis of less collagen and looser elastic fibers has benefited the patient for two reasons: 1) Formation of lower density fibrous bundles in the myocardium allow less arrhythmogenic substrate, reducing the risk of sudden death from lethal arrhythmia; 2) Less fibrosis allows consequently lower diastolic rigidity and increased coronary flow, more oxygen supply and nutrients, less functional ischemia and reduced chance to progress to systolic dysfunction and heart failure.

It is also possible to suggest that, indirectly, TNX deficit has a beneficial effect in the left ventricle due to influences on compliance of the aorta. The case of this patient suggests no development of arterial rigidity with aging and thus turns out to be protected from the effects of low compliance. ${ }^{10}$

These assumptions and their physiological and electrophysiological implications probably explain the benign evolution of $\mathrm{OHC}$ in this patient, motivated by a genetic defect in the expression of TNX in the cardiac tissue, also suggesting that the same defect plays a protective effect against the low compliance of the aorta due to advanced age in this clinical case.

\author{
M AILING ADDRESS: \\ Raimundo J osé A Imeida Pinto \\ Programa de Pós Graduação em Enfermagem eSaúde \\ José M oreira Sobrinho Street, s/n \\ Jequiezinho \\ 45206-190 - Jequié - BA \\ Brazil \\ E-mail: rjapinto@superig.com.br
}

H ow to cite this article: Pinto RJAO, Santos AA, Azevedo MC, Meira SS. Ehlers-Danlos Syndrome associated with cardiomyopathy hypertrophic obstructive. An Bras Dermatol. 2015;90(3 Suppl 1):S220-22. 